\title{
ICHTHYOPHTHIRIOSIS - CAUSE OF SIGNIFICANT LOSSES OF CARP FINGERLINGS
}

\author{
Miroslav Ćirković ${ }^{*}$, Nikolina Novakov ${ }^{2}$, Brankica Kartalović, ${ }^{1}$ \\ Miloš Pelić ${ }^{1}$, Sanja Jovanić́ 3 , Biljana Božić ${ }^{1}$, Vesna Đorđević ${ }^{4}$ \\ ${ }^{1}$ Scintific Veterinary Institute „Novi Sad“, Novi Sad, Serbia \\ ${ }^{2}$ Faculty of Agriculture, Novi Sad, Serbia \\ ${ }^{3}$ Institute of Chemistry, Technology and Metallurgy, Beograd, Serbia \\ ${ }^{4}$ Institute of Meat Hygiene and Technology, Beograd, Serbia
}

\section{Abstract}

Ichthyophthiriosis is widespread parasitic disease of fishes caused by a ciliated protozoan, Ichthyophthirius multifilis. This parasite is capable of affecting most of species of freshwater fishes, including all cyprinids. The parasites usually can be found on skin and gill in the form of white prominent spots 0.1-1 $\mathrm{mm}$ in diameter, which looks as if the fish was sprinkled with grits. Within these tissues, infections cause localized lymphocyte infiltration, focal necrosis and varying degrees of epithelial proliferation. Investigations were carrieed out during a last 10 years, while monitoring the health condition of carp fish. Diagnosis of ichthyophthiriosis was performed by clinical and microscopic examination. Disease was present in carps throughout their life, but the most susceptible were young categories. The parasites were present on the skin and gills earlier in 10-day-old fingerlings. The outbreaks are most common in spring, after overwintering when water temperatures increase and also does the parasite replication rate. High stock density, water quality and poor condition contribute to illness. Since the disease causes significant losses of carp fingerlings it is necessary to perform its adequate controls and therapy. In order to prevent the disease it is need to to rear young fish separately from other fish categories, prevent weed fishes from entering the ponds and employ hygienic and prophylactic measures. All technological measures which can improve the condition of fish are most effective against ichthyophthiriosis. It is important to add lime into the pond from time to time. Effective chemical treatments for $I$.

${ }^{1 \star}$ e-mail: miroslavcirkovic@yahoo.com 
multifiliis include copper sulfate, potassium permanganate, malachite green, salt and formalin. Malachite green is a teratogen, and prohibited for use, while copper sulfate, potassium permanganate and formalin are also under currently reviewing for the use as parasiticides in food fish. So that, non-iodized salt is the only permitted and safe therapeutic for the moment.

Key words: Ichthyophthirius multifilis, carp fingerlings, losess, preventive measurements

\title{
IHTIOFTIRIOZA - UZROK ZNAČAJNIH GUBITAKA KOD MLADUNACA ŠARANA
}

\author{
Miroslav Ćirković..$^{*}$, Nikolina Novakov ${ }^{2}$, \\ Brankica Kartalović, ${ }^{1}$ Miloš Pelić 1 , \\ Sanja Jovanić 3 , Biljana Božić ${ }^{1}$, Vesna Đorđević ${ }^{4}$ \\ ${ }^{1}$ Naučni institut za veterinarstvo „Novi Sad“, Novi Sad, Srbija \\ ${ }^{2}$ Poljoprivredni fakultet, Novi Sad, Srbija \\ ${ }^{3}$ Institut za hemiju, tehnologiju i metalurgiju, Beograd, Srbija \\ ${ }^{4}$ Institut za higijenu i tehnologiju mesa, Beograd, Srbija
}

\section{Kratak sadržaj}

Ihtioftirioza je široko rasprostranjeno parazitsko obolenje izazvano protozoom, trepljašem Ichthyophthirius multifilis. Ovaj parazit može dovesti do infekcije kod skoro svih slatkovodne vrsta riba, uključujući i sve ciprinidne vrste. Parazit se najčešće nalazi na koži i škrgama, u vidu belih uzdignutih tačkica veličine 0.1-1 mm, pri čemu riba izgleda kao da je posuta grizom. U zahvaćenom tkivu dolazi do stvaranja lokalizovanih infiltracija limfocitima, fokalne nekroze i različitog stepena epitelne proliferacije. Istraživanja su sprovedena tokom poslednjih 10 godina, u sklopu praćenja zdravstvenog stanja šaranskih riba. Dijagnoza ihtioftirioze je postavljena na osnovu kliničkog i mikroskopskog pregleda. Obolenje je bilo prisutno kod svih starosnih kategorija šarana, dok su najosetljiviji bili mladunci. Najranije je ovaj parazit bio prisutan na koži i škrgama kod deset dana starih mladunaca šarana. Pojava obolenja najčešća je tokom proleća nakon prezimljavanja ribe kada dolazi do povećanja temperature a takođe i ubrzanog razmnožavanja parazita, odnosno razvojnih oblika. Vielika gustina nasada, 
slab kvalitet vode i loši uslovi držanja itekako doprinose pojavi ovog obolenja. Imajući u vidu da I. multifilis dovodi do značajnih gubitaka šaranske mlađi veoma je važna adekvatna kontrola i terapija ovog obolenja. U cilju preveniranja bolesti neophodno je gajiti mladunce odvjeno od drugih kategorija riba, sprečavati ulazak korovske ribe i održavati opšte higijenske i profilaktičke mere. Sve tehnološke mere koje imaju za cilj poboljšanje kondicije riba takođe su efikasne u preventivi ihtioftirioze. $S$ vremena na vreme u ribnjake treba dodavati i kreč. $U$ efikasna terapeutska sredstva za I. multifilis spadaju bakar sulfat, kalijum permanganat, malahit zeleno, so i formalin. Malahit zeleno je teratogen i zabranjen za upotrebu, dok su bakar sulfat, kalijum permanganat i formalin pod trenutnim nadzorom da li bi smeli da se koriste kao antiparazitici kod riba namenjenih za konzum. Za sada je nejonizovana so jedino dozvoljeno i sigurno terapeutsko sredstvo.

Ključne reči: Ichthyophthirius multifilis, mladunci šarana, gubici, preventivne mere

\section{INTRODUCTION}

Ichthyophthiriosis, also known as ich or white spot disease is a cosmopolitan parasitosis of fishes (Nigrelli et al., 1976; Valtonen and Keränen, 1981). Infections have been reported from all regions where fishes are cultured, from the Equator to the Arctic Circle (Rinramaki-Kinnanen and Valtonen, 1997; Valtonen et al., 1994). I. multifiliis is believed to have originated as a parasite of carp (Hoffman, 1999). Ich appears to parasitize all freshwater fishes. There are no records of species with complete natural resistance (Ventura and Paperna, 1985). Ichthyophthirius multifilis is the largest known parasitic protozoan found on fishes. Adult organisms are oval to round and measure 0.3 to $1.0 \mathrm{~mm}$ in size and can be visible by the naked eye. The adult is uniformly ciliated and contains a horseshoe-shaped nucleus which can be seen in older individuals. Parasite has a simple life cycle consisting of three developmental stages each of which is ciliated: the infective form (theront), the host associated form (trophont) and the encysted environmental form (tomont) (Hines and Spira, 1973). The motile theront ( $30 \times 60 \mu \mathrm{m}$ in size) has limited energy reserves and remains infectious for approximately three days (Dickerson and Dawe, 1995). It penetrates under the epithelium, feeds on cells and tissue fluids and transforms into the next stadium - trophont (Ewing and Kocan, 1986). When fully developed, trophonts abandon the host and transforms into tomonts. The life cycle of I. multifiliis is influenced by water temperature. A single round of replication occurs in $4-5$ days at water temperatures of $20-24^{\circ} \mathrm{C}$ (Ewing et al., 1986). The 
parasite cannot survive in water temperature greater than $30^{\circ} \mathrm{C}$. At colder temperatures $\left(<10^{\circ} \mathrm{C}\right)$ parasite development is slowed. Epizootics usually occur during spring and summer months when warmer water temperatures increase parasite replication rate and reduced levels of dissolved oxygen cause stress in fish populations (Maki, 2002). Other factors influencing the severity of infection include stocking density, water quality, and susceptibility of various fish species (Johnson, 1993). Lesions associated with I. multifiliis infection have been well characterized. The classic sign of infection is presence of small white spots on the skin or gills $0.1-1 \mathrm{~mm}$ in diameter. Prior to the appearance of white spots, fish may show signs of irritation, flashing, weakness, loss of appetite, and decreased activity. If the parasite is only present on the gills, white spots will not be seen at all, but fish will die in large numbers (Francis-Floyd and Reed, 1991). In these fish, gills will be pale and very swollen. The diagnosis is established by light microscopy, when the parasites are found in fresh skin and gill samples (Francis-Floyd and Reed, 2011). Thomits are continuously moving, while the trophonts are located cysts. In order to prevent the disease it is need to to rear young fish separately from other fish categories, prevent weed fishes from entering the ponds and employ hygienic and prophylactic measures (Ćirković and Novakov, 2013). The most used chemical treatments for I. multifiliis include copper sulfate, potassium permanganate, malachite green, salt and formalin (Johnson, 1993). Commercial aquaculture operations are limited to using only those compounds approved for food fish and are hampered by the cost of treating large volumes of water for extended periods of time. The goal of this paper is to do a survey of ichthyophthiriosis in carp fish pond, of Serbia and to indicate the importance of the disease, as well as to perform and recommend the most appropriate preventive and therapeutic measures.

\section{MATERIALS AND METHODS}

Diagnostics and investigations were conducted during last 10 years, while monitoring the health condition of carp fish. Over a 10-year period more than thousands of samples were examined for the presence of Ichthyophthirius multifilis. The examined fishes originated from 18 common carp fish ponds in Serbia. Fish were collected with a net and suspected fish were transported alive to the laboratory where they were processed.

Samples for microscopic examination were taken from tissue of gill arch, the body surface and a tail fin. We removed several white spots from an infected fish, then mount them on a microscope slide with a few drops of water 
and a cover glass. The mature parasite is the large $(200$ to $800 \mu \mathrm{m})$ ciliated trophonts which were easily seen in unstained wet mounts $(\times 10-40$ magnification). The trophont of Ichthyophthirius multifilis has a distinctive horseshoeshaped nucleus, which is a pathognomonic sign of infection. In early or very heavy infections, theronts were also present.

\section{RESULTS AND DISCUSSION}

During the investigations(study) Ichthyophthirius multifilis (Figure 1) was present in all carp categories, but the most susceptible were carp fingerlings where in some ponds mortality ranged up to $90 \%$. The parasites were present on the skin and gills in 10-day-old carp fingerlings earlier. The outbreaks were most common in spring, after overwintering when water temperatures increased as well as parasite replication rate, but the fish immunity is still weaker. Also, the disease was present in ponds with high stock density, lower water quality and poor condition which contributed to the illness.

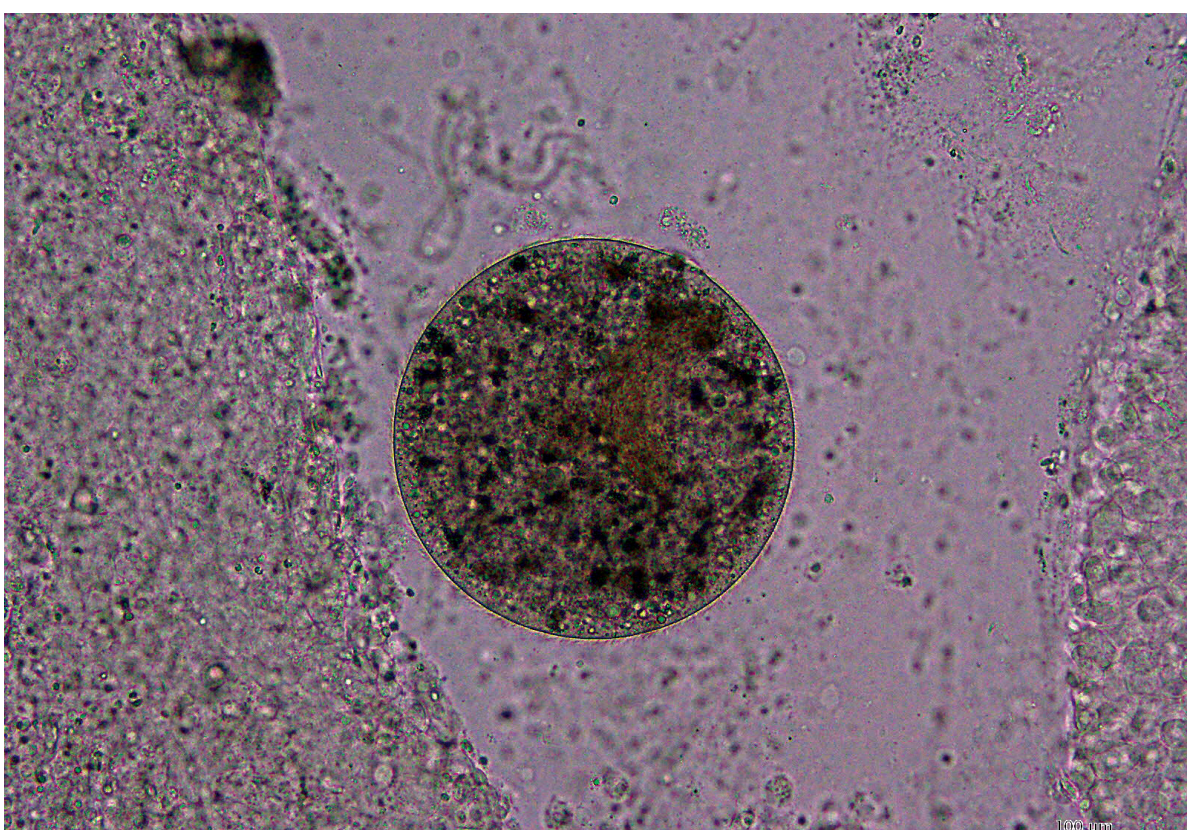

Figure 1. Ichthyophthirius multifilis trophont with characteristic horseshoe-shaped nucleus. (Bar $=100 \mu \mathrm{m})$. 
At the beginning of the disease there were no visible changes in the fish behaviour, but as the infection intensifies the fish were agitated, moving quickly to the water surface, swiming in circles and were less reactive to external stimuli. Fish infected with I. multifiliis demonstrated an aberrant behavior called "flashing" (i.e., darting or making quick movements against objects in their environment). This behavior may be seen early in infection before parasites are visible on the exterior surface of the fish. On the skin there were necroses in the form of white spots $0.1-1 \mathrm{~mm}$ in diameter, which looks as if the fish was sprinkled with grits (Figure 2).

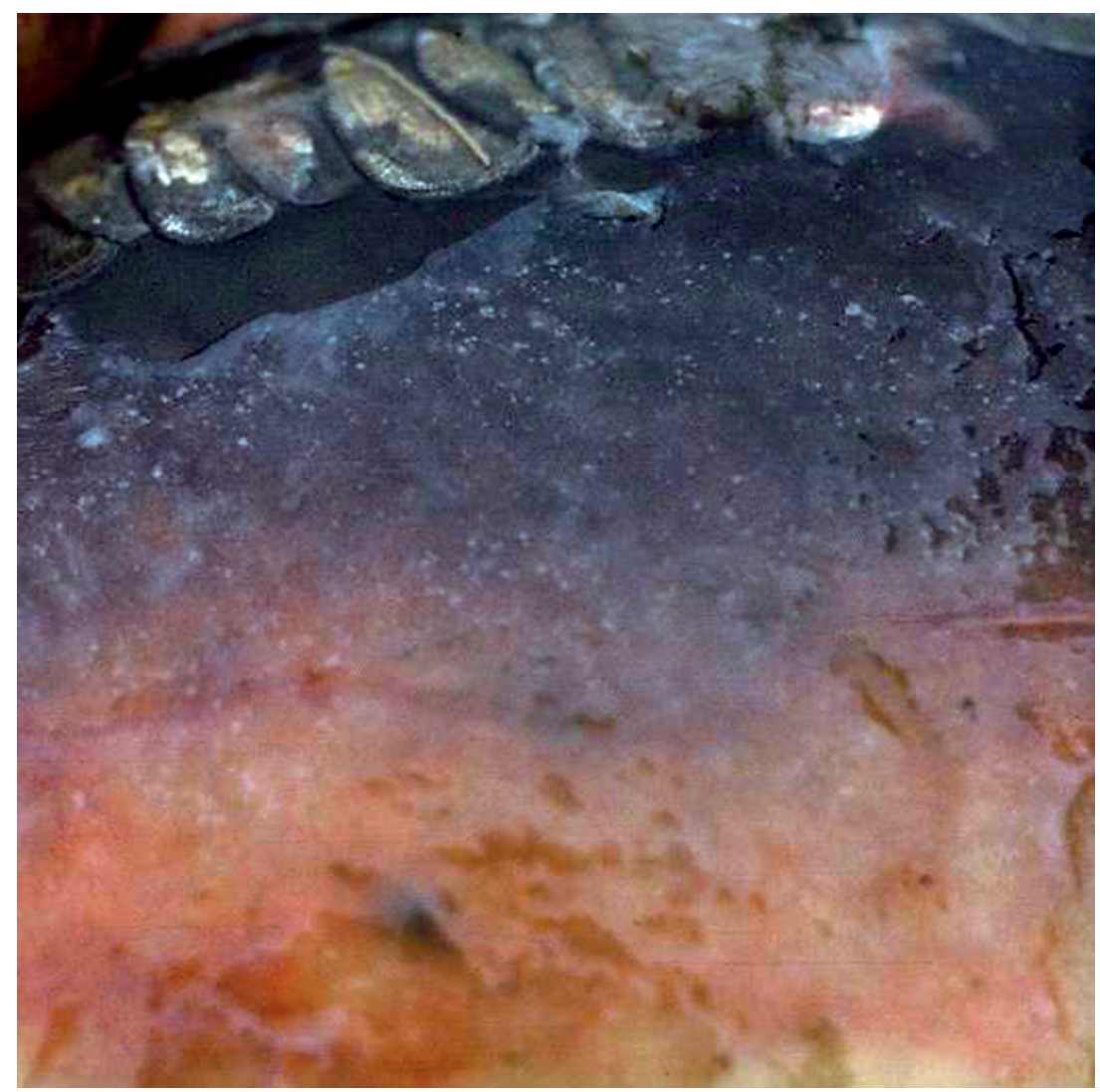

Figure 2. Ichthyophthiriosis in carp with characteristic skin lesions.

Intense infections resulted in death, when fish died in large numbers, especially when parasites were present on the gills, which were pale and very swollen, so asphyxia was the cause of the death. Lesions made by parasites may 
become infected with bacteria and especially fungi of which saprolegnia being the most frequent one (Figure 4).

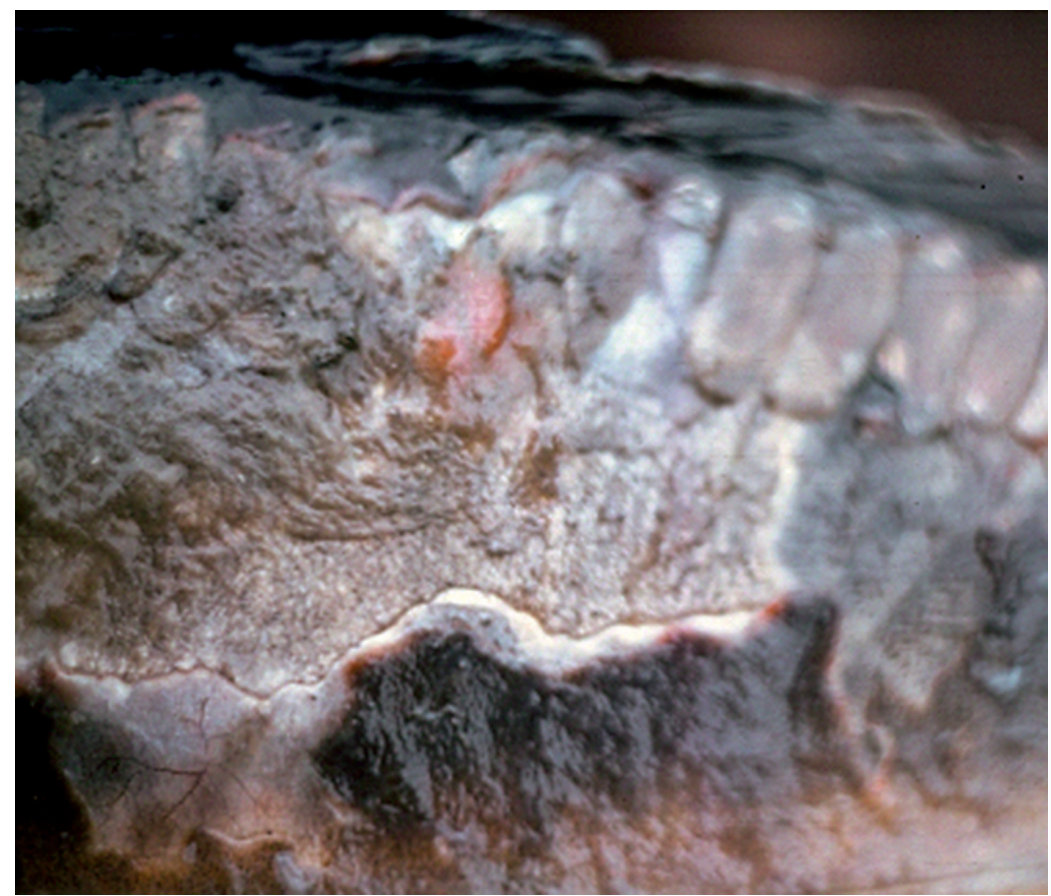

Figure 3. Ichthyophthiriosis in a carp-secondary infection with fungi of Saprolegnia species

Ichthyophthiriosis is highly important disease because is one of the most common diseases in freshwater fishes and can cause mortality rate up to 100\% (Meyer, 1974; Maki, 2002; Ćirković and Novakov, 2013). Mild infections may resolve without treatment, but in closed systems multiple rounds of replication usually result in heavy parasite loads and high mortality. Infected fish often die due to impaired respiration and disrupted osmoregulation (Hines and Spira, 1974). Disease control and prevention in an intensive fish production is the most important and depend upon an integrated management program. The basic is to prevent the fish from the exposure of the parasites, identify the disease if it occurs and perform treatment of infected fishes.

In order to prevent the disease it is necessary to rear young fish separately from other fish categories and prevent weed fishes from entering the ponds. This is because fish which contracted the disease are the source of the infection 
as well as some weed fish species. Also all hygienic and prophylactic measures are necessary combatting this disease. All technological measures which can improve the condition of fish (nutrition, reduction of stress, good water quality) are effective against ichthyophthiriosis. It is also important to add lime into the pond from time to time. Effective chemical treatments for I. multifiliis include copper sulfate, potassium permanganate, malachite green, salt and formalin (Francis-Floyd and Reed, 2011; Johnson, 1993). Malachite green is a teratogen, and prohibited for use. Copper sulfate must be taken into consideration since copper sulphate is toxic at low $\mathrm{pH}$ and can diminish the oxygen content in water and lead to lethality. If the alkality is less than $50 \mathrm{ppm}$ the application of copper sulphate is not advisable (Watson and Yanong, 2011). Copper sulfat, potassium permanganate and formalin are also under currently reviewing for the use as parasitic ides in food fish. So that, Non-iodized salt is the only permitted and safe therapeutic for use. Salt can be used to control white spot disease in small volumes of water. (i.e., tanks or vats). Fish can be dipped in a $3 \%(30,000 \mathrm{mg} / \mathrm{l})$ solution for thirty seconds to several minutes, or they can be treated in a prolonged bath at a lower concentration $(0.05 \%=500$ mg/l) (Francis-Floyd and Reed, 2011).

\section{CONCLUSION}

Ichthyophthiriosis is one of the most common diseases in freshwater fishes. White spot disease were present on the skin and gills in 10-day-old carp fingerlings earlier, and caused mortality rate up to $90 \%$. The outbreaks were most common in spring and connected with high stock density, lower water quality and poor condition. Characteristic white spots $0.1-1 \mathrm{~mm}$ in diameter, were present on the skin of infectede fish. Separate breading of carp fry from older fish categories, disable the entrance of wild fish, technological measures (optimal density, feeding, reduction of stress, good water quality) and lime addition are necessary for combatting this disease. Using of non-iodized salt is also effective in the control of the disease.

\section{ACKNOWLEDGMENT}

This work is supported by a grant from the Ministry of Education, Science and Technological Development, Republic of Serbia, Project number TR 31011. 


\section{LITERATURE}

1. Ćirković M., Novakov N.: Parazitske bolesti ciprinidnih riba, Naučni institut za veterinarstvo Novi Sad, Elman štampa, 2013.

2. Dickerson W., Dawe L.: Ichthyophthirius multifiliis and Cryptocaryon irritans (Phylum Ciliophora), pp. 181-221. In P.T.K. Woo (ed.) Fish Diseases and Disorders. Wallingford, UK, CAB International, 1995.

3. Ewing S., Kocan M.: Ichthyophthirius multifiliis (Cilophora) developement in gill epithelium, J Protozool, 33, 369-374. 1986.

4. Ewing S., Lynn E., Ewing A.: Critical periods in development of Ichthyophthirius multifiliis (Ciliophora) populations. J Protozool, 33, 3, 388-391, 1986.

5. Francis-Floyd R., Reed P.: Ichthyophthirius multifiliis (White Spot) Infections in Fish, Institute of Food and Agricultural Sciences, University of Florida, UF/IFAS Extension publications, 2011.

6. Hines S., Spira T.: Ichthyophthirius multifiliis (Fouquet) in the mirror carp, Cyprinus carpio L. I. Course of infection. J. Fish Biol, 5, 385-392, 1973.

7. Hines S., Spira T.: Ichthyophthirius multifiliis (Fouquet) in the mirror carp Cyprinus carpio L., IV. Physiological dysfunction. J Fish Biol, 6, 365-371, 1974.

8. Hoffman G.: Parasites of North American Fishes. Ithaca, New York, Comstock Publishing Associates, 1999.

9. Johnson M.: The veterinary approach to channel catfish. pp. 249-270. In L. Brown (ed.), Aquaculture for Veterinarians. Tarrytown, NY, USA, Pergamon Press, Inc., 1993.

10. Maki J.L.: Ichthyophthirius multifiliis Infection and Elements of Mucosal Immunity in the Channel Catfish, (Ictalurus punctatus), Doctoral thesis, The University of Georgia, pp 136. (in English), 2002.

11. Meyer P.: Parasites of freshwater fishes. Part 2. Protozoa 3, Ichthyophthirius multifiliis. Washington, DC Fish DiseaseLeaflet No. 2, United States department of the Interior, U.S.F.W.S. 1974.

12. Nigrelli F., Pokorny S. Ruggieri D.: Notes on Ichthyophthirius multifilis, a ciliate parasitic on freshwater fishes, with some remarks on possible physiological races and species. Transactions of the American Microscopical Soceity, 95, 607-613, 1976.

13. Rinramaki-Kinnanen P., Valtonen T.: Epizootiology of protozoans in farmed salmonids at northern latitudes. Intl J Parasitol. 27, 10, 89-99, 1997.

14. Valtonen T., Keränen A.: Ichthyophthiriasis of Atlantic salmon, Salmo salar L. at the Montta Hatchery in northern Finland in 1978-1979. Journal of Fish Diseases, 4, 405-411, 1981. 
15. Valtonen T., Koskivaara M.: Relationship between the parasites of some wild and culture fishes in two lakes and a fish farm in central Finland. Intl J Parasitol, 24, 1,109-118, 1994.

16. Watson C., Yanong R.P.E.: Use of Copper in Freshwater Aquaculture and Farm Ponds, Institute of Food and Agricultural Sciences, University of Florida, UF/IFAS Extension publications, 2011.

Primljeno: 20.08.2015.

Odobreno: 02.09.2015. 